\title{
Anilinolysis of Diethyl Phosphinic Chloride in Acetonitrile
}

\author{
Nilay Kumar Dey and Hai Whang Lee* \\ Department of Chemistry, Inha University, Incheon 402-751, Korea. *E-mail: hwlee@inha.ac.kr \\ Received March 3, 2010, Accepted March 17, 2010
}

Key Words: Anilinolysis, Diethyl phosphinic chloride, Deuterium kinetic isotope effect, Steric effect

Nucleophilic substitution at a phosphoryl $(\mathrm{P}=\mathrm{O})$ or thiophosphoryl $(\mathrm{P}=\mathrm{S})$ center generally proceeds either through stepwise mechanism with a trigonal bipyramidal pentacoordinate (TBP-5C) intermediate or a concerted $\mathrm{S}_{\mathrm{N}} 2$ mechanism with a TBP-5C transition state (TS). ${ }^{1}$ Continuing the studies on phosphoryl transfer reactions, ${ }^{2}$ the reactions of diethyl phosphinic chloride $\left[\mathrm{Et}_{2} \mathrm{P}(=\mathrm{O}) \mathrm{Cl} ; 2\right]$ with substituted anilines $\left(\mathrm{XC}_{6} \mathrm{H}_{4} \mathrm{NH}_{2}\right)$ are investigated kinetically in acetonitrile at $50.0{ }^{\circ} \mathrm{C}$ (eq 1). The deuterium kinetic isotope effects (DKIEs; $k_{\mathrm{H}} / k_{\mathrm{D}}$ ) involving deuterated aniline $\left(\mathrm{XC}_{6} \mathrm{H}_{4} \mathrm{ND}_{2}\right)$ nucleophiles are also investigated, since the DKIEs are one of the strong tools to clarify the reaction mechanism. The DKIEs have provided a useful means to determine the TS structures in nucleophilic substitution reactions, and how the reactants, especially through changes in substituents, alter the TS structures. ${ }^{3}$ Incorporation of deuterium in the nucleophile has an advantage in that the $\alpha$-DKIEs reflect only the degree of bond formation. When partial deprotonation of the aniline occurs in a rate-limiting step by hydrogen bonding, the $k_{\mathrm{H}} / k_{\mathrm{D}}$ values are greater than unity, primary normal $\left(k_{\mathrm{H}} / k_{\mathrm{D}}>\right.$ $1.0){ }^{4}$ In contrast, the DKIEs can only be secondary inverse $\left(k_{\mathrm{H}} / k_{\mathrm{D}}<1.0\right)$ in a normal $\mathrm{S}_{\mathrm{N}} 2$ reaction, since the $\mathrm{N}-\mathrm{H}(\mathrm{D})$ vibrational frequencies invariably increase upon going to the TS because of an increase in steric congestion in the bond-making process. ${ }^{4}$ This work aims to gain further information into the phosphoryl transfer reactions, as well as to compare the mechanism and DKIEs of the anilinolyses of dimethyl $\left[\mathrm{Me}_{2} \mathrm{P}(=\mathrm{O}) \mathrm{Cl}\right.$; 1] ${ }^{2 \mathrm{i}}$ methyl phenyl $[\mathrm{MePhP}(=\mathrm{O}) \mathrm{Cl} ; 3],{ }^{2 \mathrm{i}}$ and diphenyl $\left[\mathrm{Ph}_{2} \mathrm{P}\right.$ $(=\mathrm{O}) \mathrm{Cl} ; 4]^{2 \mathrm{~d}}$ phosphinic chlorides in $\mathrm{MeCN}$.

$$
\begin{aligned}
\mathrm{Et}_{2} \mathrm{P}(=\mathrm{O}) \mathrm{Cl}+2 \mathrm{NL}_{2} \mathrm{C}_{6} \mathrm{H}_{4} \mathrm{X} \quad \frac{\mathrm{MeCN}}{50.0{ }^{\circ} \mathrm{C}} \\
\mathrm{Et}_{2} \mathrm{P}(=\mathrm{O}) \mathrm{NLC}_{6} \mathrm{H}_{4} \mathrm{X}+\mathrm{XC}_{6} \mathrm{H}_{4} \mathrm{NL}_{3}{ }^{+} \mathrm{Cl}^{-} \\
\mathrm{L}=\mathrm{H} \text { or D } \\
\mathrm{X}=4-\mathrm{MeO}, 4-\mathrm{Me}, 3-\mathrm{Me}, \mathrm{H}, 3-\mathrm{MeO}, 4-\mathrm{Cl} \text {, and } 3-\mathrm{Cl}
\end{aligned}
$$

The observed pseudo-first-order rate constants $\left(k_{\text {obsd }}\right)$ were found to follow eq 2 for all of the reactions under pseudo-firstorder conditions with a large excess of aniline nucleophile.

$$
k_{\text {obsd }}=k_{0}+k_{\mathrm{H}(\mathrm{D})}\left[\mathrm{XC}_{6} \mathrm{H}_{4} \mathrm{NH}_{2}\left(\mathrm{D}_{2}\right)\right]
$$

The $k_{0}$ values were negligible $\left(k_{0}=0\right)$ in MeCN. The secondorder rate constants $\left(k_{\mathrm{H}(\mathrm{D})}\right)$ were determined for at least five concentrations of anilines. The linear plots of eq 2 suggest that there is no base-catalysis or noticeable side reactions and that the overall reaction is described by eq 1 . The $k_{\mathrm{H}}$ and $k_{\mathrm{D}}$ values are summarized in Table 1 , together with the DKIEs $\left(k_{\mathrm{H}} / k_{\mathrm{D}}\right)$ and the Hammett $\rho_{X}$ and Brönsted $\beta_{\mathrm{X}}$ selectivity parameters. The $\mathrm{p} K_{\mathrm{a}}$ values of the anilines in water are used to obtain the Brönsted $\beta_{\mathrm{X}}$ values in $\mathrm{MeCN}$, and this procedure are justified experimentally and theoretically. ${ }^{5}$ The $\mathrm{p} K_{\mathrm{a}}$ and $\sigma$ values of the deuterated anilines are assumed to be identical to those of the anilines. The stronger nucleophile leads to the faster rate as observed in a typical nucleophilic substitution reaction. The magnitudes of the $\rho_{\mathrm{X}}$ and $\beta_{\mathrm{X}}$ values of the reactions of 2 with the deuterated anilines are somewhat smaller than those with the anilines, suggesting less sensitivity to substituent effects of the deuterated anilines compared to anilines. The same tendency was observed for the anilinolyses of $1,{ }^{2 \mathrm{i}} \mathbf{3},{ }^{2 \mathrm{i}}$ and $44^{2 \mathrm{~d}}$ The DKIEs are secondary inverse, $k_{\mathrm{H}} / k_{\mathrm{D}}<1$, and a weaker nucleophile leads to a greater secondary inverse (or smaller value of $k_{\mathrm{H}} / k_{\mathrm{D}}$ ).

Figure 1 shows the B3LYP/6-311+G(d,p) geometries, ${ }^{6}$ natural bond order (NBO) charges, ${ }^{6}$ and rate ratios of the anilinolyses (unsubstituted aniline) of $\mathbf{1},{ }^{2 \mathrm{i}} \mathbf{2}, \mathbf{3}^{2 \mathrm{i}}$ and $\mathbf{4}^{2 \mathrm{~d}}$ at $55.0^{\circ} \mathrm{C}$. The NBO charges on the reaction center $\mathrm{P}$ are $+1.793,+1.817,+1.821$, and +1.844 in $\mathbf{1}, \mathbf{2}, \mathbf{3}$, and $\mathbf{4}$, respectively, which are consistent with the summation of the inductive effects of the two ligands,

Table 1. The second-order rate constants $\left(k_{\mathrm{H}(\mathrm{D})} \times 10^{2} / \mathrm{M}^{-1} \mathrm{~s}^{-1}\right)$, selectivity parameters $\left(\rho_{X}\right.$ and $\left.\beta_{\mathrm{X}}\right),{ }^{a}$ and deuterium kinetic isotope effects $\left(k_{\mathrm{H}} / k_{\mathrm{D}}\right)$ for the reactions of diethyl phosphinic chloride (2) with $\mathrm{XC}_{6} \mathrm{H}_{4} \mathrm{NH}_{2}\left(\mathrm{D}_{2}\right)$ in $\mathrm{MeCN}$ at $50.0^{\circ} \mathrm{C}$

\begin{tabular}{cccc}
\hline $\mathrm{X}$ & $k_{\mathrm{H}} \times 10^{2} / \mathrm{M}^{-1} \mathrm{~s}^{-1}$ & $k_{\mathrm{D}} \times 10^{2} / \mathrm{M}^{-1} \mathrm{~s}^{-1}$ & $k_{\mathrm{H}} / k_{\mathrm{D}}$ \\
\hline $4-\mathrm{MeO}$ & $44.4 \pm 0.2^{b}$ & $45.6 \pm 0.6$ & $0.974 \pm 0.001^{i}$ \\
$4-\mathrm{Me}$ & $29.8 \pm 0.9$ & $31.2 \pm 0.9$ & $0.955 \pm 0.001$ \\
$3-\mathrm{Me}$ & $23.0 \pm 0.6$ & $25.1 \pm 0.7$ & $0.931 \pm 0.001$ \\
$\mathrm{H}$ & $16.2 \pm 0.6$ & $17.7 \pm 0.3$ & $0.915 \pm 0.001$ \\
$3-\mathrm{MeO}$ & $11.8 \pm 0.3$ & $13.2 \pm 0.4$ & $0.894 \pm 0.003$ \\
$4-\mathrm{Cl}$ & $6.89 \pm 0.04$ & $8.08 \pm 0.20$ & $0.853 \pm 0.003$ \\
$3-\mathrm{Cl}$ & $4.24 \pm 0.06$ & $5.12 \pm 0.06$ & $0.828 \pm 0.003$ \\
$-\rho_{\mathrm{X}}$ & $1.59 \pm 0.05^{c, d}$ & $1.48 \pm 0.05^{f, g}$ & \\
$\beta_{\mathrm{X}}$ & $0.56 \pm 0.03^{c, e}$ & $0.52 \pm 0.03^{f, h}$ & \\
\hline
\end{tabular}

${ }^{a}$ The $\sigma$ values were taken from Hansch, C.; Leo, A.; Taft, R. W. Chem. Rev. 1991, 91, 165. The $\mathrm{p} K_{\mathrm{a}}$ values of $\mathrm{X}$-anilines in water were taken from Streitwieser, A. Jr.; Heathcock, C. H.; Kosower, E. M. Introduction to Organic Chemistry, 4th ed.; Macmillan: New York, 1992; p 735. ${ }^{b}$ Standard deviation. ${ }^{c}$ Calculated from $k_{\mathrm{H}} .{ }^{d}$ Correlation coefficient, $\mathrm{r}=0.998 .{ }^{e} \mathrm{r}=$ 0.998. ${ }^{f}$ Calculated from $k_{\mathrm{D}} \cdot{ }^{g} \mathrm{r}=0.993 .{ }^{h} \mathrm{r}=0.993$. ${ }^{i}$ Standard error $\left\{=1 / k_{\mathrm{D}}\right.$ $\left.\left[\left(\Delta k_{\mathrm{H}}\right)^{2}+\left(k_{\mathrm{H}} / k_{\mathrm{D}}\right)^{2} \times\left(\Delta k_{\mathrm{D}}\right)^{2}\right]^{1 / 2}\right\}$ from Crumpler, T. B.; Yoh, J. H. Chemical Computations and Errors; John Wiley: New York, 1940; 178. 

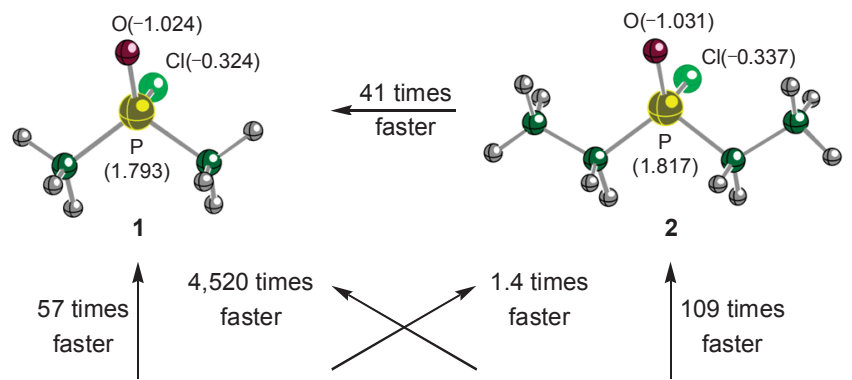

A

109 times faster

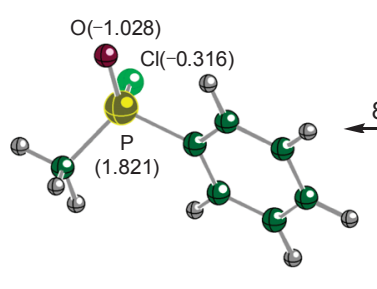

3

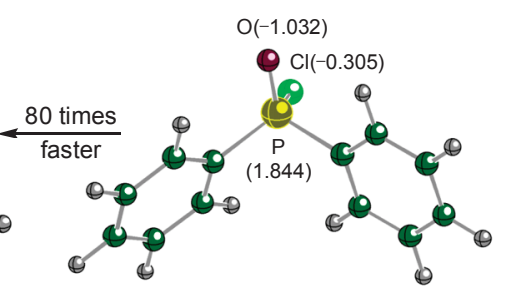

4
Figure 1. The B3LYP/6-311+G(d,p) geometries and NBO charges of $\mathbf{1},{ }^{2 \mathrm{i}} \mathbf{2}, \mathbf{3},{ }^{2 \mathrm{i}}$ and $\mathbf{4}^{2 \mathrm{~d}}$ in the gas phase. The anilinolysis $\left(\mathrm{C}_{6} \mathrm{H}_{5} \mathrm{NH}_{2}\right)$ rate ratios in $\mathrm{MeCN}$ at $55.0^{\circ} \mathrm{C}$ are displayed next to the arrows.

$\mathrm{R}_{1}$ and $\mathrm{R}_{2}, \sum \sigma_{\mathrm{I}}: \sum \sigma_{\mathrm{I}}=-0.02(\mathbf{1}) ;-0.02(\mathbf{2}) ; 0.11(\mathbf{3}) ; 0.24(\mathbf{4})$ with $\mathrm{Me}\left(\sigma_{\mathrm{I}}=-0.01\right)$, Et $\left(\sigma_{\mathrm{I}}=-0.01\right)$, and $\mathrm{Ph}\left(\sigma_{\mathrm{I}}=0.12\right)$ ligands. $^{7}$ Solely considering the magnitudes of the positive charge on the reaction center Patom (or the electrophilicity of P), the sequence of the anilinolysis rate should be $\mathbf{4}>\mathbf{3}>\mathbf{2}>\mathbf{1}$. However, the observed sequence of the rate, $1>>2>3>>4$, is surprisingly contrary to expectations for the electronic influence of the two ligands. Thus, there is no doubt that the electrophilicity of the substrate is not the major factor to determine the reactivity of the phosphinic chloride system.

The second-order rate constants for the anilinolyses of four phosphinates, $\mathbf{1}, \mathbf{2}, \mathbf{3}$, and $\mathbf{4}$, give the relative rates of $4,520\left(k_{\mathrm{H}}=\right.$ $\left.782 \times 10^{-2}\right)^{8}: 109\left(k_{\mathrm{H}}=18.9 \times 10^{-2}\right)^{9}: 80\left(k_{\mathrm{H}}=13.8 \times 10^{-2}\right)^{2 \mathrm{i}}:$ $1\left(k_{\mathrm{H}}=0.173 \times 10^{-2} \mathrm{M}^{-1} \mathrm{~s}^{-1}\right)^{2 \mathrm{~d}}$ in MeCN at $55.0^{\circ} \mathrm{C}$. It is evident that the sequence of the anilinolysis rates of the phosphinic chlorides, $\mathbf{1}>\mathbf{2}>\mathbf{3}>\mathbf{4}$, is inversely proportional to the sizes of the two ligands; $\mathrm{Ph}, \mathrm{Ph}(\mathbf{4})>\mathrm{Ph}, \mathrm{Me}(\mathbf{3})>\mathrm{Et}$, $\mathrm{Et}(\mathbf{2})>\mathrm{Me}$, $\mathrm{Me}$ (1). A plot of $\log k_{\mathrm{H}}$ (unsubstituted aniline at $55.0^{\circ} \mathrm{C}$ ) of the anilinolyses of three phosphinic chlorides; $\mathbf{1}, \mathbf{3}$, and $\mathbf{4}$ against the Taft's steric constants according to eq, $\log k_{\mathrm{H}}=\delta \Sigma E_{\mathrm{S}}+\mathrm{C}$, gave the great sensitivity coefficient of the steric effects, $\delta=$ 0.737 (incidentally good linearity ; $\mathrm{r}=0.999$ ), where $\Sigma E_{\mathrm{S}}$ is the sum of the Taft's steric constants (Figure 2). ${ }^{10}$ These results indicate that the anilinolysis rates of phosphinic chlorides are predominantly dependent on the steric effects over the inductive effects of the two ligands.

However, as seen in Figure 2, the anilinolysis of $\mathbf{2}$ exhibits a large negative deviation from the slope of $\delta=0.737$. This suggests that the steric effects of the two ethyl ligands in $\mathbf{2}$ are greater than the reference reaction, ${ }^{10}$ resulting in slower rate than expected one from the $\Sigma E_{\mathrm{S}}$ values. The rate ratio of $k_{\mathrm{H}}(\mathbf{2}) /$ $k_{\mathrm{H}}(\mathbf{3})=1.4$ implies that the steric effects on the anilinolysis rate of two ethyl ligands is slightly smaller than those of methyl and phenyl ligands (vide infra).

The selectivity parameters $\left(\rho_{\mathrm{X}}\right.$ and $\left.\beta_{\mathrm{X}}\right)$ and DKIEs $\left(k_{\mathrm{H}} / k_{\mathrm{D}}\right)$

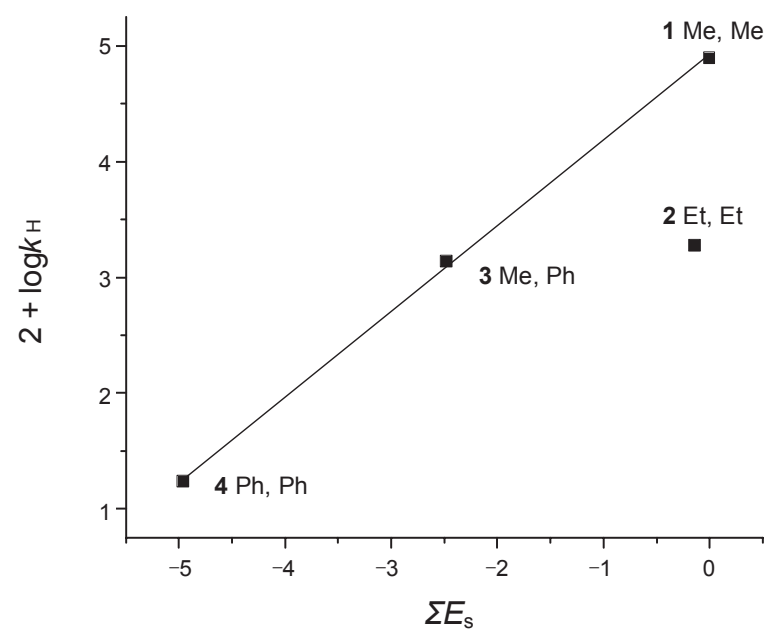

Figure 2. The plot of $\log k_{\mathrm{H}}$ against $\Sigma E_{\mathrm{S}}$ of the reactions of 1, 2, 3, and 4 with $\mathrm{C}_{6} \mathrm{H}_{5} \mathrm{NH}_{2}$ in $\mathrm{MeCN}$ at $55.0^{\circ} \mathrm{C} . \delta=0.737$ (from 1, 3, and $\mathbf{4} ; \mathrm{r}=$ $0.999)$ and $\delta=0.572$ (from 1, 2, 3, and 4; r = 0.895). $\Sigma E_{\mathrm{S}}=0.00\left(\mathrm{Me}_{2}\right)$, $-0.14\left(\mathrm{Et}_{2}\right),-2.48(\mathrm{MePh})$, and $-4.96\left(\mathrm{Ph}_{2}\right)$ from $E_{\mathrm{S}}=0.00(\mathrm{Me}),-0.07$ (Et) and $-2.48(\mathrm{Ph}) .{ }^{10}$ The two ligands, $\mathrm{R}_{1}$ and $\mathrm{R}_{2}$, are displayed next to the substrate numbers.

Table 2. The selectivity parameters, $\rho_{\mathrm{X}}$ and $\beta_{\mathrm{X}}$, and $k_{\mathrm{H}} / k_{\mathrm{D}}$ values of the reactions of $\mathbf{1}, \mathbf{2}, \mathbf{3}$, and $\mathbf{4}$ with $\mathrm{XC}_{6} \mathrm{H}_{4} \mathrm{NH}_{2}\left(\mathrm{D}_{2}\right)$ in $\mathrm{MeCN}$

\begin{tabular}{lcccc}
\hline \multicolumn{1}{c}{ Substrate } & $-\rho_{\mathrm{X}}$ & $\beta_{\mathrm{X}}$ & $k_{\mathrm{H}} / k_{\mathrm{D}}$ & ref. \\
\hline $\mathbf{1} \mathrm{Me}_{2} \mathrm{P}(=\mathrm{O}) \mathrm{Cl}$ & $4.59^{a}$ & $1.62^{a}$ & $0.740-0.945^{a}$ & $2 \mathrm{i}$ \\
$\mathbf{2} \mathrm{Et}_{2} \mathrm{P}(=\mathrm{O}) \mathrm{Cl}$ & $1.59^{b}$ & $0.56^{b}$ & $0.828-0.974^{b}$ & This work \\
$\mathbf{3} \mathrm{MePhP}=\mathrm{O}) \mathrm{Cl}$ & $3.74^{c}$ & $1.35^{c}$ & $1.62-2.10^{c}$ & $2 \mathrm{i}$ \\
$\left.\mathbf{4} \mathrm{Ph}_{2} \mathrm{P}=\mathrm{O}\right) \mathrm{Cl}$ & $4.78^{c}$ & $1.69^{c}$ & $1.42-1.82^{c}$ & $2 \mathrm{~d}$
\end{tabular}

${ }^{a}$ Values at $15.0{ }^{\circ} \mathrm{C} .{ }^{b}$ Values at $50.0{ }^{\circ} \mathrm{C}$. ${ }^{c}$ Values at $55.0{ }^{\circ} \mathrm{C}$.

for the reactions of $\mathbf{1}, \mathbf{2}, \mathbf{3}$, and $\mathbf{4}$ with anilines in $\mathrm{MeCN}$ are summarized in Table 2 . The DKIEs of $\mathbf{1}\left(k_{\mathrm{H}} / k_{\mathrm{D}}=0.740-0.945\right)^{2 \mathrm{i}}$ and $2\left(k_{\mathrm{H}} / k_{\mathrm{D}}=0.828-0.974\right)$ are secondary inverse, while those of $\mathbf{3}\left(k_{\mathrm{H}} / k_{\mathrm{D}}=1.62-2.10\right)^{2,11}$ and $\mathbf{4}\left(k_{\mathrm{H}} / k_{\mathrm{D}}=1.42-1.82\right)^{2 \mathrm{~d}, 11}$ are primary normal. The authors proposed that the anilinolysis of $\mathbf{1}$ predominantly proceeds through a concerted mechanism involving TS I on the basis of the secondary inverse DKIEs, since the two small methyl groups readily enable backside nucleophilic attack. On the contrary, the anilinolyses of $\mathbf{3}$ and $\mathbf{4}$ predominantly proceed through a concerted mechanism involving a hydrogen-bonded four-center-type TS II on the basis of the considerably large primary normal DKIEs, since frontside attack is more favorable than backside attack due to the large sizes of the two ligands.

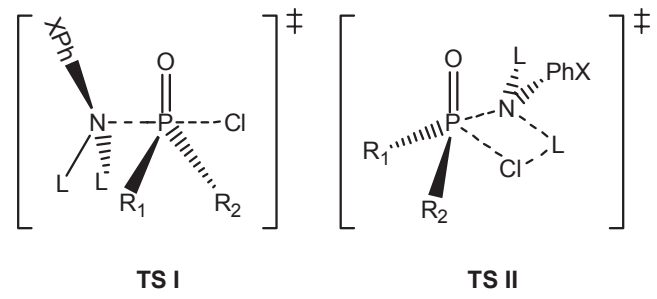

The magnitudes of the Hammett $\left(\rho_{X}=-1.59\right)$ and Brönsted 
$\left(\beta_{\mathrm{X}}=0.56\right)$ coefficients of 2 are considerably smaller than those $\left(\rho_{\mathrm{X}}=-2.72\right.$ to -4.78 and $\left.\beta_{\mathrm{X}}=0.96-1.69\right)$ of sixteen $\mathrm{R}_{1} \mathrm{R}_{2} \mathrm{P}(=\mathrm{O}$ or S)Cl-type substrates in $\mathrm{MeCN}$, in which the reaction mechanism is a concerted $\mathrm{S}_{\mathrm{N}} 2$ pathway. ${ }^{2 \mathrm{a}-\mathrm{j}}$ The anilinolysis of $\mathrm{Y}-\mathrm{O}$-aryl methyl phosphonochloridothioates $\left[\mathrm{Me}\left(\mathrm{YC}_{6} \mathrm{H}_{4} \mathrm{O}\right) \mathrm{P}(=\mathrm{S}) \mathrm{Cl}\right]$ in $\mathrm{MeCN}$ exceptionally yielded small values of $\rho_{\mathrm{X}}=-0.38$ to -1.28 and $\beta_{\mathrm{X}}=0.14-0.46$ for strongly basic anilines, but great values of $\rho_{\mathrm{X}}=-4.10$ to -4.84 and $\beta_{\mathrm{X}}=1.31-1.54$ for weakly basic anilines. ${ }^{2 \mathrm{k}}$ Moreover, the DKIEs were primary normal $\left(k_{\mathrm{H}} / k_{\mathrm{D}}=\right.$ $1.03-1.30)$ for stronger nucleophiles and unprecedented large secondary inverse $\left(k_{\mathrm{H}} / k_{\mathrm{D}}=0.367-0.567\right)$ for weaker nucleophiles. ${ }^{12}$ The proposed mechanism was a concerted $\mathrm{S}_{\mathrm{N}} 2$ and stepwise with rate-limiting leaving group expulsion from the intermediate for strongly and weakly basic anilines, respective$1 \mathrm{y} .{ }^{2 \mathrm{k}}$ Thus, in the present work, a concerted $\mathrm{S}_{\mathrm{N}} 2$ mechanism involving a backside nucleophilic attack (TS I) is proposed on the basis of the relatively small magnitudes of selectivity parameters ( $\rho_{\mathrm{X}}$ and $\beta_{\mathrm{X}}$ ), and the secondary inverse DKIEs. Furthermore, with respect to the small magnitudes of selectivity parameters, early TS can be proposed.

As discussed earlier, both the reactivity and nucleophilic attacking direction of the studied reaction system are dominantly dependant on the steric effects of the two ligands, $R_{1}$ and $R_{2}$. The greater steric hindrance of these ligands occurs, the slower rate becomes. A backside nucleophilic attack is favorable until the severe steric hindrance prohibits backside attack and consequently frontside attack becomes predominant. Although diethyl ligands exhibit slower rate than expected one from the $\Sigma E_{\mathrm{S}}$, the degree of steric hindrance of diethyl ligands is small enough to enable a backside attack (vide supra).

In summary, the reactions of diethyl phosphinic chloride (2) with $\mathrm{X}$-anilines are studied kinetically in acetonitrile at $50.0{ }^{\circ} \mathrm{C}$. The steric effect over the inductive effect is the major factor to determine the reactivity and nucleophilic attacking direction. The secondary inverse DKIEs $\left(k_{\mathrm{H}} / k_{\mathrm{D}}=0.828-0.974\right)$ involving deuterated aniline $\left(\mathrm{XC}_{6} \mathrm{H}_{4} \mathrm{ND}_{2}\right)$ nucleophiles are obtained. The small magnitudes of $\rho_{\mathrm{X}}$ and $\beta_{\mathrm{X}}$ values and secondary inverse DKIEs suggest a concerted mechanism involving a backside nucleophilic attack.

\section{Experimental Section}

Materials. Diethyl phosphinic chloride and HPLC-grade $\mathrm{MeCN}$ (water content is less than $0.005 \%$ ) were used for kinetic studies without further purification. Anilines were redistilled or recrystallized before use. Deuterated anilines were synthesized by heating anilines and deuterium oxide (99.9 atom \% D) and one drop of $\mathrm{HCl}$ catalyst at $90{ }^{\circ} \mathrm{C}$ for 72 hours, and after numerous attempts, anilines were deuterated more than $98 \%$, as confirmed by ${ }^{1} \mathrm{H}$ NMR.

Kinetics measurement. Rates were measured conductometrically as previously described. ${ }^{2 \mathrm{a}-\mathrm{r}}[$ Substrate $]=0.1 \mathrm{M}$ and $[$ Nucleophile $]=(0.01 \sim 0.07) \mathrm{M}$ were used for the present work. Pseudo-first-order rate constant values were the average of three runs that were reproducible within $\pm 3 \%$.

Product analysis. Diethyl phosphinic chloride was reacted with excess anilines for more than 15 half-lives at $50.0{ }^{\circ} \mathrm{C}$ in $\mathrm{MeCN}$. The anilinium chloride salt was separated by filtration.
Analytical data of the product gave the following results:

$\left(\mathbf{C}_{2} \mathbf{H}_{5}\right)_{2} \mathbf{P}(=\mathbf{O}) \mathbf{N H C}_{6} \mathbf{H}_{5}$ : Light yellow solid, $\mathrm{mp}(52-54){ }^{\circ} \mathrm{C}$; ${ }^{1} \mathrm{H} \mathrm{NMR}\left(400 \mathrm{MHz}, \mathrm{CDCl}_{3}\right) \delta 1.086-1.169\left(6 \mathrm{H}, \mathrm{m}, \mathrm{CH}_{3}\right), 1.821-$ $1.911\left(4 \mathrm{H}, \mathrm{m}, \mathrm{CH}_{2}\right), 5.361-5.383(1 \mathrm{H}, \mathrm{d}, J=8.8 \mathrm{~Hz}, \mathrm{NH}), 6.676-$ $7.256\left(5 \mathrm{H}, \mathrm{m}\right.$, arometic); ${ }^{13} \mathrm{C} \mathrm{NMR}\left(100 \mathrm{MHz}, \mathrm{CDCl}_{3}\right) \delta 20.200$ $\left(\mathrm{CH}_{3}, \mathrm{~s}\right), 21.049\left(\mathrm{CH}_{2}, \mathrm{~s}\right), 115.031-141.031(\mathrm{C}=\mathrm{C}$, aromatic); ${ }^{31} \mathrm{P}$ NMR $\left(162 \mathrm{MHz}, \mathrm{CDCl}_{3}\right) \delta 50.303-50.360(1 \mathrm{P}, \mathrm{d}, J=9.2$ $\mathrm{Hz}, \mathrm{P}=\mathrm{O}) ; \mathrm{m} / z, 197\left(\mathrm{M}^{+}\right)$; found: $\mathrm{C}$ 60.93, H 8.37, N 7.15; $\mathrm{C}_{10} \mathrm{H}_{16} \mathrm{NOP}$, requires C 60.90, H 8.18, N 7.10\%.

Acknowledgments. This work was supported by Inha University Research Grant.

\section{References and Notes}

1. (a) Hudson, R. F. Structure and Mechanism in Organophosphorus Chemistry; Academic Press: London, 1965; Chapter 3. (b) Thatcher, G. R. J.; Kluger, R. Adv. Phys. Org. Chem. 1989, 25, 99. (c) Williams, A. Concerted Organic and Bio-Organic Mechanisms; CRC Press: Boca Raton, 2000; Chapter 7-8. (d) Hengge, A. C. Adv. Phys. Org. Chem. 2005, 40, 49. (e) Kumara Swamy, K. C.; Satish Kumar, N. Acc. Chem. Res. 2006, 39, 324. (f) Um, I. H.; Shin, Y. H.; Han, J. Y.; Mishima, M. J. Org. Chem. 2006, 71, 7715. (g) Um, I. H.; Akhtar, K.; Shin, Y. H.; Han, J. Y. J. Org. Chem. 2007, 72, 3823. (h) Kirby, A. J.; Souza, B. S.; Medeiros, M.; Priebe, J. P.; Manfredi, A. M.; Nome, F. Chem. Commun. 2008, 4428. (i) Um, I. H.; Han, J. Y.; Hwang, S. J. Chem. Eur. J. 2008, 14, 7324. (j) Um, I. H.; Han, J. Y.; Shin, Y. H. J. Org. Chem. 2009, 74, 3073.

2. Anilinolysis: (a) Guha, A. K.; Lee, H. W.; Lee, I. J. Chem. Soc., Perkin Trans. 2 1999, 765. (b) Lee, H. W.; Guha, A. K.; Lee, I. Int. J. Chem. Kinet. 2002, 34, 632. (c) Hoque, M. E. U.; Dey, S.; Guha, A. K.; Kim, C. K.; Lee, B. S.; Lee, H. W. J. Org. Chem. 2007, 72, 5493. (d) Hoque, M. E. U.; Lee, H. W. Bull. Korean Chem. Soc. 2007, 28, 936. (e) Dey, N. K.; Han, I. S.; Lee, H. W. Bull. Korean Chem. Soc. 2007, 28, 2003. (f) Hoque, M. E. U.; Dey, N. K.; Kim, C. K.; Lee, B. S.; Lee, H. W. Org. Biomol. Chem. 2007, 5, 3944. (g) Dey, N. K.; Hoque, M. E. U.; Kim, C. K.; Lee, B. S.; Lee, H. W. J. Phys. Org. Chem. 2008, 21, 544. (h) Lumbiny, B. J.; Lee, H. W. Bull. Korean Chem. Soc. 2008, 29, 2065. (i) Dey, N. K.; Hoque, M. E. U.; Kim, C. K.; Lee, B. S.; Lee, H. W. J. Phys. Org. Chem. 2009, 22, 425. (j) Dey, N. K.; Kim, C. K.; Lee, H. W. Bull. Korean Chem. Soc. 2009, 30, 975. (k) Hoque, M. E. U.; Guha, A. K.; Kim, C. K.; Lee, B. S.; Lee, H. W. Org. Biomol. Chem. 2009, 7, 2919. Pyridinolysis: (1) Guha, A. K.; Lee, H. W.; Lee, I. J. Org. Chem. 2000, 65, 12. (m) Lee, H. W.; Guha, A. K.; Kim, C. K.; Lee, I. J. Org. Chem. 2002, 67, 2215. (n) Adhikary, K. K.; Lee, H. W.; Lee, I. Bull. Korean Chem. Soc. 2003, 24, 1135. (o) Hoque, M. E. U.; Dey, N. K.; Guha, A. K.; Kim, C. K.; Lee, B. S.; Lee, H. W. Bull. Korean Chem. Soc. 2007, 28, 1797. (p) Adhikary, K. K.; Lumbiny, B. J.; Kim, C. K.; Lee, H. W. Bull. Korean Chem. Soc. 2008, 29 , 851. (q) Lumbiny, B. J.; Adhikary, K. K.; Lee, B. S.; Lee, H. W. Bull. Korean Chem. Soc. 2008, 29, 1769. (r) Dey, N. K.; Hoque, M. E. U.; Kim, C. K.; Lee, H. W. J. Phys. Org. Chem. DOI 10.1002/ poc.1709. Theoretical: (s) Lee, I.; Kim, C. K.; Li, H. G.; Sohn, C. K.; Kim, C. K.; Lee, H. W.; Lee, B. S. J. Am. Chem. Soc. 2000, $122,11162$.

3. (a) Lee, I.; Koh, H. J.; Lee, B. S.; Lee, H. W. J. Chem. Soc., Chem. Commun. 1990, 335. (b) Lee, I. Chem. Soc. Rev. 1995, 24, 223. (c) Marlier, J. F. Acc. Chem. Res. 2001, 34, 283. (d) Westaway, K. C. Adv. Phys. Org. Chem. 2006, 41, 217. (e) Villano, S. M.; Kato, S.; Bierbaum, V. M. J. Am. Chem. Soc. 2006, 128, 736. (f) Gronert, S.; Fajin, A. E.; Wong, L. J. Am. Chem. Soc. 2007, 129, 5330.

4. (a) Poirier, R. A.; Youliang, W.; Westaway, K. C. J. Am. Chem. Soc. 1994, 116, 2526. (b) Yamata, H.; Ando, T.; Nagase, S.; Hanamusa, M.; Morokuma, K. J. Org. Chem. 1984, 49, 631. (c) Xhao, X. G.; Tucker, S. C.; Truhlar, D. G. J. Am. Chem. Soc. 1991, 113, 826. 
5. (a) Ritchie, C. D. In Solute-Solvent Interactions; Coetzee, J. F., Ritchie, C. D., Eds.; Marcel Dekker: New York, 1969; Chapter 4. (b) Coetzee, J. F. Prog. Phys. Org. Chem. 1967, 4, 54. (c) Spillane, W. J.; Hogan, G.; McGrath, P.; King, J.; Brack, C. J. Chem. Soc., Perkin Trans. 2 1996, 2099. (d) Oh, H. K.; Woo, S. Y.; Shin, C. H.; Park, Y. S.; Lee, I. J. Org. Chem. 1997, 62, 5780.

6. Hehre, W. J.; Random, L.; Schleyer, P. V. R.; Pople, J. A. Ab Initio Molecular Orbital Theory; Wiley: New York, 1986; Chapter 4.

7. Charton, M. Prog. Phys. Org. Chem. 1987, 16, 287.

8. The value of $k_{\mathrm{H}}=7.82 \times 10^{\circ} \mathrm{M}^{-1} \mathrm{~s}^{-1}$ at $55.0^{\circ} \mathrm{C}$ was obtained by extrapolation in the Arrhenius plot $(\mathrm{r}=0.999)$ with kinetic data: $k_{\mathrm{H}}=0.776,1.01$, and $1.61 \times 10^{0} \mathrm{M}^{-1} \mathrm{~s}^{-1}$ at $0.0,5.0$, and $15.0{ }^{\circ} \mathrm{C}$, respectively, from ref. $2 \mathrm{i}$.

9. The value of $k_{\mathrm{H}}=18.9 \times 10^{-2} \mathrm{M}^{-1} \mathrm{~s}^{-1}$ at $55.0^{\circ} \mathrm{C}$ was obtained by extrapolation in the Arrhenius plot $(\mathrm{r}=0.999)$ with kinetic data:
$k_{\mathrm{H}}=11.7,16.2$, and $21.1 \times 10^{-2} \mathrm{M}^{-1} \mathrm{~s}^{-1}$ at $40.0,50.0$, and $60.0^{\circ} \mathrm{C}$, respectively, from this work.

10. Taft, R. W. Steric Effect in Organic Chemistry; Newman, M. S., Ed,; Wiley: New York, 1956; Chapter 3.

11. The value of $k_{\mathrm{H}} / k_{\mathrm{D}}=2.10$ for the reaction of $3[\mathrm{MePhP}(=\mathrm{O}) \mathrm{Cl}]$ with 4-methoxy aniline in $\mathrm{MeCN}$ at $55.0{ }^{\circ} \mathrm{C}$ is the largest one observed for the anilinolyses of $\mathrm{R}_{1} \mathrm{R}_{2} \mathrm{P}(=\mathrm{O}$ or $\mathrm{S})$ Cl-type substrates. Although the primary normal DKIEs $\left(k_{\mathrm{H}} / k_{\mathrm{D}}=1.62-2.10\right)$ of 3 are greater than those $\left(k_{\mathrm{H}} / k_{\mathrm{D}}=1.42-1.82\right)$ of $4\left[\mathrm{Ph}_{2} \mathrm{P}(=\mathrm{O}) \mathrm{Cl}\right]$, there is no doubt that the anilinolyses of both substrates predominantly proceed through frontside nucleophilic attack. The subtle combination of $\mathrm{Me}$ and $\mathrm{Ph}$ gave an interesting result.

12. The DKIE of $k_{\mathrm{H}} / k_{\mathrm{D}}=0.367$ for the reaction of $O$-4-cyanophenyl methyl phosphonochloridothioates with 4-chloro aniline in MeCN at $55.0{ }^{\circ} \mathrm{C}$ is unprecedented greatest secondary inverse. 